\title{
Maternal outcome in antepartum eclampsia caesarean versus vaginal delivery
}

\author{
Nihar Ranjan Behera, Jaiminkumar Patel*
}

Department of Obstetrics and Gynecology, MKCG Medical college, Berhampur, Odisha, India

Received: 05 February 2018

Accepted: 03 March 2018

\section{*Correspondence:}

Dr. Jaiminkumar patel,

E-mail: dr.jaiminmpatel@gmail.com

Copyright: ( $)$ the author(s), publisher and licensee Medip Academy. This is an open-access article distributed under the terms of the Creative Commons Attribution Non-Commercial License, which permits unrestricted non-commercial use, distribution, and reproduction in any medium, provided the original work is properly cited.

\begin{abstract}
Background: The term eclampsia is derived from a Greek word, meaning "like a flash of lightening". The onset of convulsions in a woman with pre-eclampsia that cannot be attributed to other causes is termed eclampsia. Eclampsia is an obstetric enigma. Though it has almost been eradicated from the developed world, it continues to be a major cause of maternal and fetal mortality and morbidity in the developing countries. The real challenge of eclampsia has not been met. In spite of considerable progress made in the field of obstetrics, the incidence of eclampsia and its consequent complications has not decreased significantly in our country over the past few decades. It is indeed sad that even today antenatal care is available only to a fraction of our rural population. However, the management of eclampsia still poses a fascinating challenge to the obstetrician, requiring the greatest skill, judgement and patience.

Methods: This is an observational and prospective study of 200 cases admitted with eclampsia in MKCG medical college. The study was extended from October 2015 to September 2017. The inclusion criteria were antepartum eclampsia, primigravida and multigravida, duration of gestation $>28$ weeks. Patients with pregnancy \& convulsion attributed to epilepsy or other causes were excluded from the study.

Results: Of the 200 cases, caesarean section was done in $51.50 \%$ of the cases, while vaginal delivery was carried out in $48.5 \%$ of the cases. It was observed the caesarean section was having better maternal outcome than vaginal delivery. Conclusions: In antepartum eclampsia in primigravidas with more than 28 weeks gestation with unfavorable cervix on admission, an early decision for caesarean section either within 6 hours of admission or 12 hours of first fit whichever is earlier is paramount in improving the maternal outcome". Prompt termination of pregnancy by caesarean section reduces maternal mortality, improves maternal outcome by reducing complications.
\end{abstract}

Keywords: Eclampsia, Maternal morbidity, Maternal mortality, Vaginal delivery

\section{INTRODUCTION}

The term eclampsia is derived from a Greek word, meaning like a flash of lightening. ${ }^{1}$ The onset of convulsions in a woman with pre-eclampsia that cannot be attributed to other causes is termed eclampsia. ${ }^{2}$

The incidence of eclampsia has often been viewed as an index of civilization in a country. The hospital incidence in India ranges from 1 in 500 to 1 in 30 . In the US the incidence of eclampsia is about 1 in 3250 pregnancies while in Europe eclampsia complicates approximately in 2000 deliveries. ${ }^{1}$ The incidence of eclampsia declined in the developed world due to adequate antenatal care and proper management of preeclampsia. However, in the developing country, the source of eclampsia continued, and its incidence varies from 1 in 100 to 1 in 1700 pregnancies. ${ }^{3}$ 
Risk factors of eclampsia include the nulliparity, family history of preeclampsia, prior preeclampsia and eclampsia, poor outcome of previous pregnancy, preexisting medical condition like obesity, hypertension, renal disease, gestational diabetes, SLE, teen pregnancy, patient older than 35 years, multifetal gestation, lower socio-economic status. ${ }^{4}$

Eclampsia is an obstetric enigma. Though it has almost been eradicated from the developed world, it continues to be a major cause of maternal and fetal mortality and morbidity in the developing countries. The real challenge of eclampsia has not been met.

Despite considerable progress made in the field of obstetrics, the incidence of eclampsia and its consequent complications has not decreased significantly in our country over the past few decades. It is indeed sad that even today antenatal care is available only to a fraction of our rural population. However, the management of eclampsia still poses a fascinating challenge to the obstetrician, requiring the greatest skill, judgement and patience. $^{5}$

Eclampsia is essentially a disease of low socio-economic status of primigravida, a product of ignorance and neglect. Ideally, it is a preventable disease or almost so. But unfortunately, its incidence is still uncomfortably high in any hospital accepting unbooked cases. Menon et al quoted an incidence of $0.83 \%$ to $1.6 \%$ from leading centres of India. ${ }^{6}$

Faced with this reality, a plan of management has to be evolved. Though the exact pathophysiology leading to the occurrence of fits is still not understood, one thing has been proved beyond doubt that termination of pregnancy, removes the basic cause of the disease. ${ }^{7}$

Keeping this in view an attempt has been made in the present study to ascertain if caesarean section has any distinct advantage over vaginal delivery in lowering maternal morbidity and mortality. ${ }^{7}$

\section{METHODS}

This is an observational and prospective study of 200 cases admitted with eclampsia in MKCG medical college. The study was extended from October 2015 to September 2017. The inclusion criteria were antepartum eclampsia, primigravida and multigravida, duration of gestation $>28$ weeks.

Patients with pregnancy and convulsion attributed to epilepsy or other causes were excluded from the study. To aim and objective of the current study is to compare the results of termination of pregnancy by caesarean section with vaginal delivery in cases of antepartum eclampsia with reference to maternal morbidity and mortality. A total of 200 cases were studied by dividing them into two groups for comparative analysis. The first group consisted of patients in whom conservative obstetric management and delivery per vaginum was carried out and was called the VD group.

The second group consisted of patient in whom lower segment caesarean section was carried out due to eclampsia and varied associated indications was called CD group.

Diagnostic criteria of eclampsia were high blood pressure (>140/90mm of $\mathrm{Hg}$ ), Significant proteinuria and convulsion associated with pregnancy more than 20 weeks of gestation. The purpose and procedure of the study was explained to the subjects who fulfilled the inclusion criteria. After taking informed written consent from the guardians of the patients, history was taken carefully and a through clinical examination was done.

The urine was tested for protein. Convulsions were controlled by magnesium sulphate $\left(\mathrm{MgSO}_{4}\right)$ if not contraindicated and blood pressure was controlled by nifedipine and labetalol IV (only given in conscious patients).

After initial management decision for termination of pregnancy was taken and mode of delivery (vaginal delivery or LSCS) was planned. The mode of delivery was noted, and the patients were followed up till discharge.

\section{Statistical analysis}

All the statistical analysis was performed by using SPSS Version 22. The statistical test was used in this study was Chi-square Test. For all statistical analysis $\mathrm{P}<0.05$ was considered statistically significant. Data was compiled, and statistical analysis was performed

\section{RESULTS}

Of the 200 cases, caesarean section was done in $51.50 \%$ of the cases, while vaginal delivery was carried out in $48.5 \%$ of the cases (Table 1 ).

Table 1: Mode of delivery.

\begin{tabular}{|lll|}
\hline Mode of delivery & Frequency & Percentage \\
\hline VD Group & 97 & 48.5 \\
\hline CD Group & 103 & 51.5 \\
\hline Total & 200 & 100 \\
\hline
\end{tabular}

Table 2 demonstrates socio-clinical characteristics of cases. Eclampsia was more common in the age group 2125 years $(53 \%)$, primigravidae $(72 \%)$ and cases with gestational age $\geq 37$ weeks. Majority $(62 \%)$ of the patients in the present study had no antenatal care. This shows lack of awareness among these patients regarding the antenatal care since majority of them are from lower socio-economic strata $(85.5 \%)$ and most of them are illiterate. 
Table 2: Socio-clinical profile.

\begin{tabular}{|c|c|c|c|c|c|}
\hline & \multicolumn{2}{|c|}{ VD Group } & \multicolumn{2}{|c|}{ CD Group } & \multirow{2}{*}{$\begin{array}{l}\text { Total } \\
\text { Cases (\%) }\end{array}$} \\
\hline & Cases & $\%$ & Cases & $\%$ & \\
\hline \multicolumn{6}{|l|}{ Age (Years) } \\
\hline$\leq 20$ & 25 & 25.77 & 24 & 23.3 & $49(24.5 \%)$ \\
\hline $21-25$ & 48 & 49.48 & 58 & 56.31 & $106(53 \%)$ \\
\hline $26-30$ & 19 & 19.59 & 18 & 17.48 & $37(18.5 \%)$ \\
\hline$>30$ & 5 & 5.15 & 3 & 2.9 & $8(4 \%)$ \\
\hline \multicolumn{6}{|l|}{ Gravida } \\
\hline G1 & 61 & 62.89 & 83 & 80.58 & $144(72 \%)$ \\
\hline $\mathrm{G} 2$ & 29 & 29.89 & 14 & 13.59 & $43(21.5 \%)$ \\
\hline G3 & 3 & 3.09 & 1 & 0.97 & $4(2 \%)$ \\
\hline$\geq \mathrm{G} 4$ & 4 & 4.13 & 5 & 4.86 & $9(4.5 \%)$ \\
\hline \multicolumn{6}{|c|}{ Gestational age } \\
\hline$\leq 34$ Weeks & 25 & 25.77 & 5 & 4.85 & $30(15 \%)$ \\
\hline 34-37 Weeks & 27 & 27.84 & 22 & 21.36 & $49(24.5 \%)$ \\
\hline$\geq 37$ Weeks & 45 & 46.39 & 76 & 73.79 & $121(60.5 \%)$ \\
\hline \multicolumn{6}{|l|}{ ANC } \\
\hline Unbooked & 58 & 59.79 & 66 & 64.1 & $124(62 \%)$ \\
\hline Booked & 39 & 40.21 & 37 & 35.9 & $76(38 \%)$ \\
\hline \multicolumn{6}{|l|}{ SES } \\
\hline Upper & 0 & 0 & 0 & 0 & $0(0 \%)$ \\
\hline Middle & 13 & 13.4 & 16 & 15.5 & $29(14.5 \%)$ \\
\hline Lower & 84 & 86.6 & 87 & 84.5 & $171(85.5 \%)$ \\
\hline
\end{tabular}

Table 3: Relation of maternal complications to $1^{\text {st }}$ convulsion-delivery interval.

\begin{tabular}{|c|c|c|c|c|c|c|}
\hline \multirow{2}{*}{$\begin{array}{l}\text { Convulsion- } \\
\text { Delivery Interval }\end{array}$} & \multicolumn{3}{|c|}{ VD Group } & \multicolumn{3}{|c|}{ CD Group } \\
\hline & Cases & Maternal complication & $\%$ & Cases & Maternal complication & $\%$ \\
\hline 0-6 Hours & 29 & 17 & 58.62 & 54 & 8 & 14.8 \\
\hline 6-12 Hours & 35 & 22 & 62.85 & 32 & 7 & 21.88 \\
\hline 12-18 Hours & 13 & 10 & 76.92 & 15 & 6 & 40 \\
\hline 18-24 Hours & 17 & 15 & 88.24 & 1 & 1 & 100 \\
\hline$\geq 24$ Hours & 3 & 3 & 100 & 1 & 1 & 100 \\
\hline Total & 97 & 66 & 67 & 103 & 24 & 23.30 \\
\hline
\end{tabular}

Table 3 shows that there was increasing in maternal complication if the $1^{\text {st }}$ convulsion and delivery interval was increased.

As the convulsion to duration increases there was increasing in maternal complication and maximum morbidity was observed if delivery was occurred after 24 hours of $1^{\text {st }}$ convulsion accounting for $100 \%$ of cases in both the group.

Table 4 shows as the duration between induction/augmentation to delivery interval increased there was increased in maternal complications. When delivery was conducted within 6 hours then maternal complications were observed in $57.14 \%$.

Maternal complications were increased to $66.67 \%$ when delivered in 6-12 hours of duration. Maximum maternal complications were observed when delivery was conducted after 18 hours from $1^{\text {st }}$ conduction.
Table 4: Relation of maternal complications to induction/ augmentation delivery interval.

\begin{tabular}{|llll|}
$\begin{array}{l}\text { Time interval } \\
\text { (Hours) }\end{array}$ & $\begin{array}{l}\text { No. of } \\
\text { cases }\end{array}$ & $\begin{array}{l}\text { Maternal } \\
\text { complication }\end{array}$ & Percentage \\
\hline 0-6 Hours & 42 & 24 & 57.14 \\
\hline 6-12 Hours & 27 & 18 & 66.67 \\
\hline 12-18 Hours & 22 & 18 & 81.81 \\
\hline 18-24 Hours & 6 & 6 & 100 \\
\hline$\geq 24$ Hours & 0 & 0 & 0 \\
\hline
\end{tabular}

Table 5 shows that pulmonary edema is the most common complication observed in both groups. pulmonary edema occurred in $12(18.46 \%)$ cases in VD Group and $6(25 \%)$ cases in CD Group, abruptio placentae occurred in $7(10.77 \%)$ cases in VD Group and $1(0.42 \%)$ case in CD Group, PPH occurred in $13(20 \%)$ cases in VD Group and 1 (0.42) case in CD Group, electrolyte imbalance seen in 11 (16.92) cases in VD 
Group and $6(25 \%)$ cases in CD Group, HELLP SYNDROME seen in $1(1.54 \%)$ case in VD Group, DIC occurred in $2(3.08 \%)$ cases in VD Group and $1(0.42 \%)$ case in CD Group, Renal failure was observed in 2 $(3.08 \%)$ case in VD Group and $1(0.42 \%)$ case in CD Group, Cortical blindness was observed in $2(3.08 \%)$ cases of VD Group, cerebral haemorrhage occurred in 5 $(7.69 \%)$ cases In VD Group and $3(12.5 \%)$ cases in CD Group, cerebral edema was seen in $11(16.92 \%)$ cases in VD Group and 5 (20.84\%) cases in CD Group.

Table 5: Maternal complications.

\begin{tabular}{|c|c|c|c|c|c|}
\hline \multirow{2}{*}{$\begin{array}{l}\text { Maternal } \\
\text { Complications }\end{array}$} & \multicolumn{2}{|c|}{ VD Group } & \multicolumn{2}{|c|}{ CD Group } & \multirow{2}{*}{ Total } \\
\hline & Cases & $\%$ & Cases & $\%$ & \\
\hline $\begin{array}{l}\text { Pulmonary } \\
\text { edema }\end{array}$ & 12 & 18.46 & 6 & 25 & 18 \\
\hline $\begin{array}{l}\text { Abruptio } \\
\text { placentae }\end{array}$ & 7 & 10.77 & 1 & 0.42 & 8 \\
\hline PPH & 13 & 20 & 1 & 0.42 & 14 \\
\hline $\begin{array}{l}\text { Electrolyte } \\
\text { imbalance }\end{array}$ & 11 & 16.92 & 6 & 25 & 17 \\
\hline $\begin{array}{l}\text { HELLP } \\
\text { syndrome }\end{array}$ & 1 & 1.54 & 0 & 0 & 1 \\
\hline DIC & 2 & 3.08 & 1 & 0.42 & 3 \\
\hline Renal failure & 2 & 3.08 & 1 & 0.42 & 3 \\
\hline $\begin{array}{l}\text { Cortical } \\
\text { blindness }\end{array}$ & 2 & 3.08 & 0 & 0 & 2 \\
\hline CVA & 5 & 7.69 & 3 & 12.5 & 8 \\
\hline $\begin{array}{l}\text { Cerebral } \\
\text { edema }\end{array}$ & 11 & 16.92 & 5 & $\begin{array}{l}20.8 \\
4\end{array}$ & 16 \\
\hline Total & 66 & 100 & 24 & 100 & 90 \\
\hline
\end{tabular}

Table 6 shows that out of 97 cases in the VD Group 66 had complications giving a maternal morbidity of $68.04 \%$ whereas out of 103 cases in CD Group 24 had complications giving a maternal morbidity of $23.3 \%$.

Chi-square equals 40.402 with 1 degree of freedom. The association is considered to be extremely statistically significant.

Table 6: Maternal morbidity.

\begin{tabular}{|llll|}
\hline $\begin{array}{l}\text { Mode of } \\
\text { delivery }\end{array}$ & $\begin{array}{l}\text { Total no. } \\
\text { of cases }\end{array}$ & $\begin{array}{l}\text { No. of } \\
\text { maternal } \\
\text { morbidity }\end{array}$ & $\begin{array}{l}\% \text { of } \\
\text { maternal } \\
\text { morbidity }\end{array}$ \\
\hline VD Group & 97 & 66 & 68.04 \\
\hline CD Group & 103 & 24 & 23.3 \\
\hline 'P' Value $=<0.0001$ (Chi Square test) & \\
\hline
\end{tabular}

Table 7 shows that pulmonary edema is the most common cause of maternal mortality in both groups. It shows that $6(42.86 \%)$ cases in VD Group and $1(50 \%)$ case in CD Group died of pulmonary edema, CVA was responsible for $3(21.43 \%)$ deaths in VD Group and $1(50 \%)$ death in CD Group, renal failure was responsible for $2(14.29 \%)$ deaths, septicaemia $1(7.14 \%)$ death, HELLP SYNDROME 1 (7.14\%) death in VD Group.
Table 7: Causes of maternal mortality.

\begin{tabular}{|llllll|}
\hline & \multicolumn{2}{l}{ VD Group } & \multicolumn{2}{l|}{ CD Group } & Total \\
\hline Causes & Cases & \% & Cases & $\%$ & \\
\hline $\begin{array}{l}\text { Pulmonary } \\
\text { Edema }\end{array}$ & 6 & 42.86 & 1 & 50 & 7 \\
\hline CVA & 3 & 21.43 & 1 & 50 & 4 \\
\hline $\begin{array}{l}\text { Hepatic } \\
\text { Failure }\end{array}$ & 1 & 7.14 & 0 & 0 & 1 \\
\hline $\begin{array}{l}\text { Renal } \\
\text { Failure }\end{array}$ & 2 & 14.29 & 0 & 0 & 2 \\
\hline Septicaemia & 1 & 7.14 & 0 & 0 & 1 \\
\hline $\begin{array}{l}\text { HELLP } \\
\text { Syndrome }\end{array}$ & 1 & 7.14 & 0 & 0 & 1 \\
\hline Total & 14 & 100 & 2 & 100 & 16 \\
\hline
\end{tabular}

Table 8: Maternal mortality.

\begin{tabular}{|llll|}
\hline & $\begin{array}{l}\text { Total no. } \\
\text { of cases }\end{array}$ & $\begin{array}{l}\text { No. of } \\
\text { maternal } \\
\text { death }\end{array}$ & $\begin{array}{l}\% \text { of } \\
\text { maternal } \\
\text { death }\end{array}$ \\
\hline VD Group & 97 & 14 & 14.43 \\
\hline CD Group & 103 & 2 & 1.94 \\
\hline 'P' Value $=$ & 0.001 (Chi square test) & \\
\hline
\end{tabular}

Table 8 shows that, out of 97 cases in VD Group, 14 died giving a maternal mortality $14.43 \%$, whereas out of 103 cases in CD Group 2 died giving a maternal mortality $1.94 \%$. Chi-square equals to 10.590 with 1 degree of freedom. The association is considered to be very statistically significant.

\section{DISCUSSION}

Eclampsia a dreaded complication in pregnancy is still associated with a great deal of maternal and fetal loss. Some decades ago the conventional treatment of eclampsia was conservative approach, with the use of sedatives anticonvulsants and antihypertensives to be followed by induction or stimulation of labour after the fits are controlled. Caesarean section was considered to be extremely risky procedure and reserved for highly selected cases. $^{8}$ Now in twenty first century with advancement in the field of anaesthesiology caesarean section in eclampsia is no riskier and promises reassuring maternal and perinatal outcome. ${ }^{8}$

In the present series 200 cases with more than 28 weeks gestation with antepartum eclampsia were studied.

- VD group where vaginal delivery was done.

- CD group where caesarean section was performed.

In our study maximum number of cases i.e. $53 \%$ in both the groups are in the age group of 21-25 years which was comparable with Sardesai et al and Swain S. ${ }^{9,10}$ The incidence of eclampsia in primigravida accounted for majority in both the group - $62.89 \%$ in VD Group and $80.59 \%$ in CD Group which was comparable with Bathla et al and Sunita TH. ${ }^{11,12}$ The highest incidence was found 
between $37-40$ weeks of gestation. $73.79 \%$ in CD group and $46.39 \%$ in VD group, the average being $60.50 \%$ which is comparable to Sunita TH. ${ }^{12}$

As our hospital was tertiary Centre for both maternal and neonatal care, these patients were referred from nearby to improve neonatal outcome. This was probably reason why majority of our patients had gestational age between $37-40$ weeks. $64.1 \%$ of cases in CD group and $59.79 \%$ of cases in VD group were booked.

Here notable fact is that $38 \%$ cases were booked in both group, still had eclamptic seizure. This was because in few cases there was no mid trimester fall of blood pressure and this was overlooked by attending doctor.

Infrequent antenatal visits and refusal to get admitted when advised were instrumental in causing eclampsia in these cases. This underscores the interplay between socio-economic status, lack of knowledge and uptake of available health resources. Majority of the patients were from rural area, where antenatal service is poor. This was comparable to Sardesai et al and S Swain..$^{9,10}$

In both the groups $62 \%$ of cases belong to low socioeconomic status. The incidence correlates well with the other studies Kanhi AK, Mundle S et al, Swain S which have found the incidence of eclampsia to be high in women of low socioeconomic status due to poverty, illiteracy and lack of proper antenatal care. ${ }^{10,13,14}$

Convulsion delivery interval is directly proportional to maternal morbidity and mortality. In present study, 66\% in VD Group and $84 \%$ in CD Group delivered within 12 hours which is similar to Sunita $\mathrm{TH} .{ }^{12}$ In present study $72 \%$ cases delivered within 12 hours of induction.

Bathla had reported a mean induction-delivery interval of 9.15 hours. ${ }^{11}$ It was Zuspan who said that delivery should be expected within 12 hours of induction with his regimen of magnesium sulphate. ${ }^{15}$ If the progress is not satisfactory then the case may be delivered by CS.

Eclampsia is responsible for considerable maternal morbidity and mortality. In our study the maternal complications were encountered in $68.04 \%$ of the cases in VD Group and $23.3 \%$ cases in CD Group.

Maternal morbidity includes Pulmonary edema, postpartum haemorrhage, abruptio placenta, acute renal failure, electrolyte imbalance, HELLP syndrome, DIC, cerebrovascular accidents (CVA) and cortical blindness. Eclampsia continues to be an important cause of maternal morbidity and mortality. This is due to lack of proper antenatal care, low socio-economic condition and lack of education.

These complications were comparable with other authors as given in Table $9 .{ }^{10,12,16}$
Table 9: Maternal complications comparable with other authors.

\begin{tabular}{|lllll|}
\hline Authors & Begum & $\begin{array}{l}\text { Sunita } \\
\text { T.H. }\end{array}$ & $\begin{array}{l}\text { S } \\
\text { Swain }\end{array}$ & $\begin{array}{l}\text { Present } \\
\text { Study }\end{array}$ \\
\hline $\begin{array}{l}\text { Pulmonary } \\
\text { edema }\end{array}$ & $10.3 \%$ & $6.9 \%$ & $8.25 \%$ & $20.22 \%$ \\
\hline PPH & $1.01 \%$ & $20.69 \%$ & $12.84 \%$ & $15.73 \%$ \\
\hline $\begin{array}{l}\text { Abruptio } \\
\text { placentae }\end{array}$ & $1.70 \%$ & $6.9 \%$ & $6.88 \%$ & $8.99 \%$ \\
\hline $\begin{array}{l}\text { HELLP } \\
\text { syndrome }\end{array}$ & $1.9 \%$ & $24 \%$ & $4.59 \%$ & $1.12 \%$ \\
\hline DIC & $1 \%$ & $10.35 \%$ & $6.42 \%$ & $3.37 \%$ \\
\hline ARF & $0.7 \%$ & $6.9 \%$ & $13.76 \%$ & $3.37 \%$ \\
\hline $\begin{array}{l}\text { Cortical } \\
\text { blindness }\end{array}$ & - & $3.45 \%$ & $3.67 \%$ & $2.25 \%$ \\
\hline CVA & $2.9 \%$ & $6.9 \%$ & $2.75 \%$ & $8.99 \%$ \\
\hline
\end{tabular}

\section{Maternal mortality}

In present study, out of 97 cases in VD Group 14 died giving a maternal mortality $14.43 \%$ whereas out of 103 cases in CD Group 2 died giving a maternal mortality $1.94 \%$ which were consistent with Habeebullah S. ${ }^{17}$ Pulmonary edema was the largest killer in our study causing $6(42.86 \%)$ deaths in VD Group and 1 (50\%) death in CD Group which was comparable with Begum. CVA was responsible for $3(21.43 \%)$ deaths in VD Group and $1(50 \%)$ death in CD Group which was consistent with Begum et al renal failure was responsible for 2 (14.29\%) deaths, septicaemia 1 (7.14\%) death, HELLP Syndrome $1(7.14 \%)$ death in VD Group which was comparable with Swain S.

\section{Table 10: Comparative incidence of maternal mortality to mode of delivery.}

\begin{tabular}{|lll|}
\hline Authors & VD Group & CD Group \\
\hline Habeebullah S & $7.10 \%$ & $4.30 \%$ \\
\hline Sunita TH & $55 \%$ & $45 \%$ \\
\hline Swain S & $52.30 \%$ & $47.70 \%$ \\
\hline Present study & $14.43 \%$ & $1.94 \%$ \\
\hline
\end{tabular}

Begum classified patients into 2 groups. One group was classified as good-outcome group; these patients were eclamptic but had no complications of eclampsia or other medical or obstetric complications. ${ }^{16}$ The other group was the poor-outcome group, who had complications related to eclampsia or other obstetric complications not related to eclampsia (e.g., obstructed labour, prolonged labour, postpartum haemorrhage). Reduction in death was difficult when patients had developed complications $98 \%$ of patients with complications died, these complications developed as a result of delayed decision for treatment.

It is not, however, the convulsions themselves that are hazardous (idiopathic epilepsy has much lower-case fatality rate) but the severity of the underlying disturbances. Therefore, the focus of secondary 
prevention should not be simply to prevent convulsions in a desperate situation but to prevent the dangerous state itself.

Most of the morbidity and mortality associated with eclampsia is caused by out of hospital seizures in unattended women and such events are seen more frequently among patients in developing countries without prenatal care and with poor medical facilities.

Cerebral haemorrhage is a complication of extreme hypertension and accounts for the undisputed benefits of therapeutic control of BP. Pulmonary edema may follow eclamptic convulsions. This may be caused by aspiration pneumonitis from aspiration of gastric contents, if simultaneous vomiting accompanies convulsions. Alternatively, it may be caused by cardiac failure as a result of a combination of severe hypertension and vigorous intravenous fluid administration. ${ }^{2}$

\section{CONCLUSION}

"In antepartum eclampsia in primigravidas with more than 28 weeks gestation with unfavorable cervix on admission, an early decision for caesarean section either within 6 hours of admission or 12 hours of first fit whichever is earlier is paramount in improving the maternal outcome". Prompt termination of pregnancy by caesarean section reduces maternal mortality, improves maternal outcome by reducing complications. Maternal outcome can be improved by taking an early decision for caesarean section when on admission cervix is unfavorable or delivery is not anticipated within 6 hours. In severe antepartum eclamptic with a closed uneffaced cervix and unengaged presenting part, it might give better results if conservative treatment is supplemented by timely caesarean section instead of withholding it.

Therefore, from my study of a small number of cases, I have come to a conclusion that caesarean section if done promptly leads to more favorable outcome than conservative obstetric management with vaginal delivery in eclampsia in primigravidae after 28 weeks of pregnancy with unfavorable cervix on admission.

"Caesarean section should be done at the optimum time and not as a last resort when conservative management has failed in eclampsia especially in primigravidas after 28 weeks of pregnancy".

\section{REFERENCES}

1. Dutta DC. Textbook of Obstetrics. $8^{\text {th }}$ Ed. Calcutta, New Central Book Agency Pvt. Ltd.;2004:234-54.

2. Hoffman B, Roberts S, Horsager R, Rogers V, Santiago-Muñoz P, Worley K. Williams Obstetrics. 24th Ed. McGraw Hill Co. Inc.;2010:761-808.
3. World Health Organization International Collaborative study of hypertensive disorder of pregnancy. Am J Obstet Gynecol. 1958;158:80-3.

4. Martin JN, JR May WL, Rinchart BK, Martin RW, Magaan EF. Increasing maternal weight; a risk factor for pre-eclampsia but apparently set for HELLP syndrome. Southern Med J. 2000;93(7):689-91.

5. Bhaskar Pal, Geeta N, Vivek P. A study of eclampsia. J Obstet Gynecol. 1996 Feb;46(1):34-9.

6. Krishna Menon. Caesarean section in eclampsia. J Obstet Gynecol Br Emp. 1961;68:461.

7. Bhattacharya PK, Purkayastha S, Basu M, Robinsanath M. Caesarean section in eclampsia: Still a dilemma. J Obstet Gynecol India. 1992;42:51-5.

8. Igberase GD, E Beigbe PN. Eclampsia: Ten years experience in a rural tertiary hospital in the Niger delta, Negeria. J Obstet Gynecol. 2006;26:414-7.

9. Sardesai SS, Maira S, Patel A, Patel U. Low dose of magnesium sulphate therapy for eclampsia and imminent eclampsia: Regime Tailored for Indian women. J Obstet Gynecol India. 2003;53:546-50.

10. Swain S, Singh S, Das L, Sahoo B. Maternal and perinatal outcome of eclampsia in a tertiary care centre. Int J Reprod Contracept Obstet Gynecol. 2016;5:384-90.

11. Bathla S, Suneja A, Guleria K, Agarwal N. Dilantin as anticonvulsant in eclampsia. J Indian Med Assoc. 2002 Sep;100(9):561-4.

12. Sunita TH, Desai RM, Hon N, Shinde KJ, Hashmi SI. Eclampsia in a teaching hospital: incidence, clinical profile and response to magnesium sulphate by Zuspan's regimen. IOSR J Dent Med Sci. 2013;4:1-5.

13. Kanhi AK. Abstracts, free communication papers, $42^{\text {nd }}$ All India Congress of Obstetrics and Gynecology, 1998.

14. Mundle S, Mullik I. Risk factors in pregnancy outcome in eclampsia. Abstracts Free Communication Papers. $42^{\text {nd }}$ All India congress of Obstetrics and Gynecology. 1998.

15. Zuspan FP. Toxemia of pregnancy, In: Sciarra JJ and Gerby AB (ed.). Gynecology and Obstetrics, Vol. 2 revised edition. Hagerstown: Harper and Row Publishers; 44.

16. Begum MR, Begum A, Quadir E, Akhter S, Shamsuddin L. Eclampsia: Still a problem in Bangladesh. Med Gen Med. 2004;6:52.

17. Habeebullah S, Agarwal A, Swain S, Arora R. Impact of mode of delivery on maternal mortality in eclampsia. JIMA. 1997;95:40.

Cite this article as: Behera NR, Patel JK, Fetal Maternal outcome in antepartum eclampsia caesarean versus vaginal delivery. Int J Reprod Contracept Obstet Gynecol 2018;7:1330-5. 